\title{
"PENGGUNAAN MEDIA VIDEO DENGAN PENDEKATAN KONSTRUKTIVISME DAPAT MENINGKATKAN KEMAMPUAN SISWA DALAM MEMPARAFRASEKAN TEKS NARRATIVE DI KELAS X MIPA 4 SMA N 1 PAGUYANGAN TAHUN PELAJARAN 2017/2018”
}

\author{
Oleh: Marcha Solicha \\ Guru Bahasa Inggris SMA N 1 Paguyangan \\ Jl. Kedung Banteng No. 1Paguyangan Brebes 52276 \\ Marchasolicha5@gmail.com
}

\begin{abstract}
Abstrak
Tujuan penelitian ini untuk mengetahui dan mendeskripsikan apakah pembelajaran menggunakan media video dengan pendekatan konstruktivisme dapat meningkatkan kemampuan siswa dalam memparafrasekan teks Narrative di kelas X MIPA 4 SMA N 1 Paguyangan Tahun Pelajaran 2017/2018, waktu penelitian berlangsung selama kurang lebih 4 bulan dengan 2 siklus. Tiap siklus dilakukan perencanaan, pelaksanaan, tindakan, observasi dan refleksi. Terdapat peningkatan kemampuan menulis pada prasiklus 65,91\%, pada siklus I sekitar 76,55\% dan pada siklus II mencapai 83,33\%. Hal ini juga terlihat pada Ulangan Harian siswa yang diajar dengan menggunakan media video dan pendekatan konstruktivisme hasilnya lebih baik dan prosentase ketuntasan belajar pun lebih tinggi dari pada sebelumnya
\end{abstract}

Kata Kunci: media video, konstruktivisme, parafrase, teks narrative.

\section{Pendahuluan}

Kemampuan memparafrase dalam bentuk menulis/writing skill sangat penting untuk diajarkan pada siswa karena menunjang ketrampilan/skill yang lain,yaitu mendengarkan, berbicara dan membaca dalam pelajaran Bahasa Inggris. Hal ini semua dituangkan dalam Permendiknas No 24 tahun 2006 tentang pelaksanaan Permendiknas No 22 dan 23 tahun 2006 tentang standar isi dan Standar Kompetensi untuk satuan Pendidikan Dasar dan Menengah.

Pada kenyataanya siswa masih kesulitan dalam menyusun kalimat baik secara lisan maupun tertulis, hal itu bisa dibuktikan pada hasil ulangan harian atau hasil tes siswa di kelas X MIPA 4 SMA N 1 Paguyangan Tahun Pelajaran 2017/2018 yang rata-rata belum mencapai KKM meski mereka sudah belajar bahasa Inggris selama kurang lebih 9 tahun. Kesulitan siswa ini didukung dengan hasil ulangan menulis narrative text yang sangat rendah dari siswa berjumlah 33 hanya 15 anak yang mendapat nilai sama dengan atau lebih dari KKM.
Berdasarkan hal tersebut maka permasalahan yang diangkat yaitu 1). Apakah penggunaan media video dengan pendekatan konstruktivisme dapat meningkatkan kemampuan siswa dalam memparafrasekan teks Narrative di kelas $X$ MIPA 4 SMA N 1 Paguyangan Tahun Pelajaran 2017/2018?

Penelitian ini bertujuan untuk Meningkatkan Kemampuan Siswa dalam Memparafrasekan Text Narrative di Kelas X MIPA 4 SMA N 1 Paguyangan Tahun Pelajaran 2017/2018 menggunakan Media Video dan Pendekatan Konstruktivisme.

\section{Kajian Pustaka}

\subsection{Media pembelajaran}

\subsubsection{Pengertian Media}

Sanjaya (2010: 204) mengatakan media pembelajaran adalah seluruh alat dan bahan yang dapat dipakai untuk tujuan pendidikan seperti radio, televisi, buku, koran, majalah, komputer dan lain sebagainya. Selain alat-alat tersebut, orang dan bahan serta peralatan yang menciptakan 
kondisi yang memungkinkan peserta didik memperoleh pengetahuan, keterampilan dan sikap juga disebut sebagai media pembelajaran. Media adalah sebuah alat yang mempunyai fungsi menyampaikan pesan, salah satunya adalah pesan pembelajaran. Sedangkan pembelajaran merupakan proses komunikasi antara peserta didik, guru, dan bahan ajar (Sanaky, 2013: 3).

Media pembelajaran dalam arti sempit hanya meliputi media yang dapat digunakan secara efektif dalam proses pembelajaran yang terencana. Sedangkan dalam arti luas, media tidak hanya meliputi media komunikasi elektronik yang kompleks, namun juga mencakup alat-alat sederhana seperti slide, fotografi, diagram, dan bagan buatan guru, kunjungan ke luar sekolah. Guru pun dianggap sebagai media penyajian, di samping radio dan televisi karena sama-sama membutuhkan dan menggunakan banyak waktu untuk menyampaikan informasi kepada para peserta didik (Hamalik, 20: 2002).

\subsubsection{Jenis-jenis media pembelajaran}

Klasifikasi media digolongkan menjadi 4 kelompok yaitu media audio, media visual, media audo visual, dan media serbaneka. Media audio visual merupakan media yang mampu menampilkan suara dan gambar. Ditinjau dari karakteristiknya media audio visual dibedakan menjadi 2 yaitu (1) media audio visual diam, dan (2) media audio visual gerak. Media audiovisual diam di antaranya TV diam, film rangkai bersuara, halaman bersuara, buku bersuara. Sedangkan media audio visual gerak di antaranya film TV, TV, film bersuara, gambar bersuara, dan lain-lain (Arsyad, 2014: 91).

\subsubsection{Fungsi media dalam Pembelajaran.}

\subsubsection{Dapat memberikan pemahaman} lebih mendalam terhadap materi pembelajaran yang dibahas

2.1.3.2 Dapat menjelaskan materi pembelajaran atau obyek yang abstrak (tidak nyata, tidak dapat dilihat langsung) menjadi konkrit (nyata, dapat dilihat, dirasakan, atau diraba.

2.1.3.3. Membantu pengajar menyajikan materi pembelajaran menjadi lebih mudah dan cepat.

2.1.3.4. Menarik dan membangkitkan minat, motivasi, aktivitas dan kreativitas belajar peserta didik.

2.1.3.5. Menstimulus partisipasi peserta didik dalam proses pembelajaran dan memberikan kesan yang mendalam dalam pikiran peserta didik.

2.1.3.6. Dapat membentuk persamaan persepsi dan pendapat yang benar terhadap suatu obyek, karena disampaikan tidak hanya secara verbal, namun dalam bentuk nyata menggunakan media pembelajaran.

2.1.3.7. Menciptakan lingkungan belajar yang kondusif, sehingga peserta didik dapat berkomunikasi dan berinteraksi dengan lingkungan tempat belajarnya dan memberikan pengalaman nyata dan langsung (Daryanto, 2012: 5-6).

\subsubsection{Tayangan Video}

Video adalah sejenis film atau gambar yang digerakkan oleh tenaga listrik. Video dapat dilihat sebagai kumpulan pesan dalam isi audio visual, sebagaimana yang diungkapkan oleh Canning - Wilson (2000). Dalam penelitian ini, video diambil dari internet dan dibentuk menjadi video pembelajaran yang dibuat secara khusus untuk pendidikan. Kitjima dan LymanHager mengungkapkan bahwa penggunaan video dalam pengajaran writing mempunyai asumsi yang terdiri dari mental representasi dan kekuatan kognitif

\subsection{Pendekatan konstruktivisme \\ Kontruktivis merupakan landasan} berpikir (filosofi) pendekatan kontekstual. Pengetahuan dibangun oleh siswa melalui kegiatan eksplorasi dan diskusi dengan temannya. Pengetahuan bukanlah seperangkat fakta, konsep, atau kaidah yang siap untuk diambil dan diangkat, tetapi siswa harus mengkonstruksi pengetahuannya sendiri. 
Kontruktivisme merupakan landasan berfikir pendekatan kontekstual, bahwa pendekatan dibangun oleh manusia sedikit demi sedikit yang hasilnya diperluas melalui konteks yang terbatas dan tidak dengan tiba-tiba(Suwarna,2005).

\subsection{Parafrase}

Parafrase adalah istilah linguistik yang berarti pengungkapan kembali suatu konsep dengan cara lain dalam bahasa yang sama, namun tanpa mengubah maknanya. Parafrase memberikan kemungkinan kepada sang penulis untuk memberi penekanan yang agak berlainan dengan penulis asli. Istilah parafrase berasal dari bahasa Inggris paraphrase, dari bahasa Latin paraphrasis, dari bahasa Yunani para phraseïn yang berarti "cara ekspresi tambahan"

Parafrasis adalah tindakan atau kegiatan untuk membuat parafrase. Parafrase dilakukan dengan cara, pertamatama teks yang akan diparafrase harus dibaca secara keseluruhan. Pembaca perlu untuk memahami topik atau tema dari teks tersebut, sedangkan untuk teks berbentuk narasi perlu memahami pula alur atau jalan ceritanya. Selanjutnya, pembaca harus menemukan gagasan atau ide pokok yang terdapat pada kalimat utama setiap paragraph. Sedangkan kalimat penjelas, hanya bagian yang penting saja yang diambil, bagian ilustrasi, seperti permisalan, dapat diabaikan. Mencertikan kembali teks tersebut, diperlukan kata atau kalimat yang sepadan, efektif, dan mudah dipahami. Agar lebih singkat, kalimat langsung dapat diubah menjadi kalimat tidak langsung. Dalam melakukan parafrasis, perlu digunakan bahasa yang ringkas dan mudah dipahami.

2.4. Narrative Text

Narrative text adalah jenis teks yang dipakai untuk menghibur pembaca atau pendengar berkaitan dengan permasalahan yang mengacu pada krisis sampai menemukan resolusi (penyelesaian masalah) yang diungkapkan oleh (Dwi Rukmini 2010: 26).
Beberapa contoh dari Narrative text mencakup dongeng, fable, legend, fairy tale - Cerita-cerita itu bisa kita lihat di TV, Video atau internet. Kita juga bisa menjumpai dalam bentuk bacaan-bacaan di buku pelajaran bahasa, internet atau buku kusus tentang dongeng. Guru-guru kita, orang tua maupun teman-teman kita juga sering menceritakan dongeng dalam bentuk story telling sehingga hal itu membuat Narrative Texts sudah tidak asing lagi bagi siswa- siswi.Meskipun demikian penulis berharap agar siswa bisa kreatif dalam menulis teks narratif yang sistimatik dan gramatical sehingga menjadi teks narrative yang berkualitas.

2.4.1. Social Function of Narrative Text (Hartono, Rudi 2005: 6-9 \& Gerot, 1995:192)

To amuse, entertain and to deal with actual or various experience in different ways.

2.4.2. Schematic structure of Narrative Text (Hartono, Rudi 2005: 6-9 \& Gerot, 1995:192):

Orientation, evaluation complication, resolution, reorientation.

2.4.3. Language feature of Narrative Texts (Hartono, Rudi 2005: 6-9 \& Gerot, 1995:192):
a. Focus on specific participants
b. Use of past tense
c. Use of temporal conjunctions and temporal circumstances
d. Use of material (or action) processes
e. Use of relational and mental processes

\subsection{Hipotesis Tindakan}

Berdasarkan pertanyaan dan landasan teori tersebut diatas, maka diduga bahwa penggunaan media Video dengan pendekatan Konstruktivisme dapat meningkatkan kemampuan siswa dalam memparafrasekan teks narrative di Kelas X 
MIPA 4 SMA N 1 Paguyangan Tahun Pelajaran 2017/2018.

\section{Metode Penelitian}

Penelitian ini merupakan penelitian tindakan kelas (PTK), yakni penelitian yang berbasis kelas atau sekolah. Penelitian ini dilakukan dengan maksud untuk meningkatkan kemantapan rasional dari tindakan-tindakan yang dilakukan. Siklus ini terdiri dari empat komponen yaitu: perencanaan, tindakan, observasi, dan refleksi (Tripp dalam Subyantoro 2009:17). Keempat komponen itu dipandang sebagai satu siklus. Jika siklus I nilai rata-rata belum mencapai target yang telah ditentukan, maka dilakukan tindakan siklus II.

Penelitian berlangsung di kelas $\mathrm{X}$ MIPA 4 SMA Negeri 1 Paguyangan yang terletak di Jalan Kedung Banteng no 1 Paguyangan, Kabupaten Brebes, Propinsi Jawa Tengah. SMA Negeri 1 Paguyangan Terletak di desa Kedung Banteng, pinggir sawah desa Paguyangan. Dari Brebes berjarak $+65 \mathrm{~km}$ dan dari Purwokerto +35 $\mathrm{km}$. Sedangkan waktu penelitian diadakan pada semester 2 (Genap) tahun ajaran 2017/2018. Penelitian dilaksanakan selama kurang lebih 4 bulan dari tanggal 2 Februari sampai dengan 15 Mei 2018.

Subjek penelitian ini adalah siswa kelas X MIPA 4 tahun pelajaran 2017/ 2018 yang berada di SMA Negeri 1 Paguyangan, Kabupaten Brebes. Jumlah subjek penelitian 33 siswa yang terdiri dari 13 siswa putra dan 20 siswa putri. Kondisi kemampuan bahasa Inggris sangat kurang karena hasil ulangan harian pada pembelajaran sebelumnya hanya mencapai rata-rata 65,91 .

Siswa kelas $\mathrm{X}$ MIPA 4 sebagai subjek penelitian ini memiliki karakteristik yang heterogen. Heterogen baik dalam segi kecakapan intelegensi, motivasi belajar, latar belakang keluarga, maupun sifat dan wataknya. Dari segi watak ada beberapa siswa yang memiliki watak sulit untuk diajak disiplin dan sulit untuk konsentrasi sehingga kadang-kadang menyulitkan guru pada saat pembelajaran berlangsung. Mereka juga berasal dari latar belakang keluarga yang berbeda, ada yang orangtuanya buruh, guru, petani, pedagang, ibu rumah tangga dan kerja serabutan. Namun secara umum siswa memiliki kepribadian yang cukup baik

Penelitian ini menggunakan rancangan Penelitian Tindakan Kelas (PTK). PTK adalah penelitian yang dilakukan oleh guru di dalam kelasnya sendiri melalui refleksi diri, dengan tujuan untuk memperbaiki kinerjanya sebagai guru, sehingga hasil belajar siswa menjadi meningkat (Wardani, 2005). Penelitian Tindakan Kelas sebagaimana dinyatakan oleh Arikunto (2010:117) merupakan penelitian yang bersiklus, terdiri dari rencana, aksi, observasi, dan refleksi yang dilakukan secara berulang, diagramnya sebagai berikut:

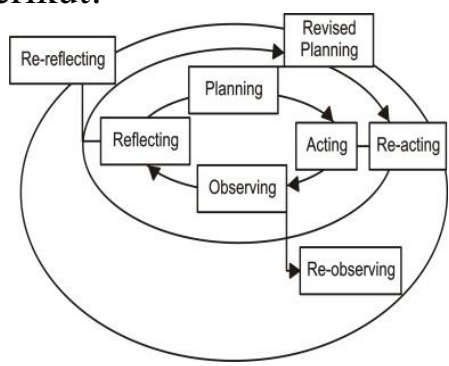

Penelitian ini menerapkan pembelajaran menggunaan media video dengan pendekatan konstruktivisme dapat meningkatkan kemampuan siswa dalam Memparafrasekan teks Narrative di kelas X MIPA 4 SMA N 1 Paguyangan Tahun Pelajaran 2017/2018"

Pada saat akan melaksanakan penelitian, penulis sudah menyusun RPP termasuk alokasi waktu, kisi-kisi soal, butir soal, kunci jawaban, media dan pendekatan yang tepat dan rubrik penilaian.

Pada saat KBM, guru memutar video tentang cerita-cerita/ dongeng kemudian peserta didik mengamati, menanya, mengeksplor dan mengkomunikasikan isi cerita dengan cara memparafrase.Pembelajaran paraphrase yang disiapkan yaitu materi/ KD narrative text. Untuk bisa memparafrase, siswa harus mengamati, mendengar dan melihat cerita lewat Audio Visual (video), ini merupakan 
tahap (Pengamatan) kemudian menanyakan isi, struktur dan unsur bahasa yang digunakan pada teks Narrative pada tahap (Menanya) dan memahami, tanya jawab isi cerita dan mengidentifikasi cirri-ciri teks Narrative pada tahap (Explorasi). Setelah mengumpulkan informasi dari tayangan video kemudian peserta didik mulai memparafrase teks Narrative baik secara lisan maupun tertulis yang hasilnya didemonstrasikan di depan guru dan peserta didik yang lain lalu dievaluasi oleh observant maupun guru, ini terjadi pada tahap (Mengkomunikasikan).

Hasil paraphrase peserta didik, dievaluasi berdasarkan rubrik penilaian hasil belajar, baik dari pengetahuan maupun ketrampilan memparafrase. Selama proses $\mathrm{KBM}$, observant dan guru juga mengamati sikap/ kepribadian dengan menggunakan instrument rubrik pengamatan sikap/kepribadian. Rubrik wawancara juga digunakan untuk mengetahui jika media video sangat berpengaruh terhadap hasil belajar siswa.

Pelaksanaan tindakan penelitian melalui siklus-siklus tindakan sebagai Penelitian Tindakan Kelas (PTK). Jumlah siklus yang direncanakan dari penelitian ini sebanyak 3 siklus, didasarkan pada aspek memparafrase teks Narrative baik lisan maupun tertulis tapi penekanan utama guru mengevaluasi hasil paraphrase peserta didik dalam bentuk tertulis. 3 Siklus yang dimaksud, guru mengadakan pra siklus untuk mengetahui hasil belajar siswa sebelum diberi perlakuan selama 2 jam pelajaran. Pada Siklus 1, guru sudah menggunakan media video dan pendekatan konstruktivisme sebagai perlakuan terhadap peserta didik saat KBM dengan alokasi waktu 2 jam pelajaran. Pada siklus 2, selain memberi perlakuan menggunakan media video dan pendekatan konstruktivisme, guru juga menyediakan guiding questions untuk mempermudah siswa dalam memparafrase teks Narrative. Hal itu dilakukan sebagai refleksi guru di siklus 1 dan dilakukan selama 2 jam pelajaran juga.
.Ada 3 macam metode pengumpulan data yang digunakan dalam penelitian ini yakni:

a. Butir soal uraian.

Butir soal disesuaikan dengan cakupan materi "Menangkap makna secara kontekstual terkait fungsi sosial dan unsur kebahasaan teks narrative.

b. Metode observasi

Lembar observasi disusun berdasarkan variabel yang diamati.

c. Wawancara

Untuk mendapatkan data yang diinginkan maka digunakan beberapa instrumen untuk mengumpulkan data sebagai berikut:

a. Lembar observasi sikap dan kepribadian selama KBM.

b. Tes hasil belajar untuk melihat tingkat pengetahuan dan ketrampilan aspek writing pada siswa, dilakukan oleh guru pada setiap akhir siklus.

c. Journal peneliti.

d. Hasil Wawancara

Untuk mengungkap kebenaran atau realita penelitian, maka analisa hasil dan refleksi digunakan Source triangulation, yakni pengambilan data dari berbagai narasumber dan Instrumental triangulation yakni menggunakan berbagai alat/instrumen pengambil data.

\section{Hasil Penelitian Dan Pembahasan}

\subsection{Hasil Penelitian}

Penilaian terhadap siswa dalam proses pembelajaran dengan Media video dan pendekatam konstriktivisme dilakukan pada saat proses belajar mengajar berlangsung baik pada siklus 1 dan siklus 2 . Penilaian pada hasil kerja siswa dilakukan oleh guru dibantu dengan kolaborator melalui tes, observasi maupun interview.

Melalui proses belajar mengajar siswa diharapkan dapat mununjukan sikap dan kepribadian yang sesuai dengan aturan dalam pembelajaran sehingga bisa menguasai berbagai ilmu pengetahuan yang diperlukan oleh siswa. Untuk mengetahui apakah siswa sudah dapat menguasainya perlu diadakan tes. Tes ini digunakan untuk 
mengetahui hasil atau prestasi belajar siswa setelah selesai mengikuti pelajaran. Setelah dilaksanakan proses belajar mengajar dengan menggunakan media video dan pendekatan konstruktivisme baik pada siklus I maupun siklus II diperoleh hasil sebagaimana tertera dalam table 1 . Berdasarkan table tersebut dapat diketahui rata-rata nilai siswa baik pada tahap pra penelitian, siklus I maupun siklus II sebagai berikut.

Tabel 1. Rata-Rata Hasil Tes Siswa

\begin{tabular}{|c|c|c|}
\hline NO & KEGIATAN & $\begin{array}{c}\text { RATA-RATA } \\
\text { HASIL TES }\end{array}$ \\
\hline 1 & Pra Siklus & 65,91 \\
\hline 2 & Siklus I & 76,55 \\
\hline 3 & Siklus II & 83,33 \\
\hline
\end{tabular}

Rumus untuk memperoleh rata-rata nilai tes adalah:

$$
\text { Rata-rata nilai }=\frac{\sum \text { nilai semua siswa }}{\sum \text { semua siswa }}
$$

Berdasarkan tabel tersebut hasil tes siswa setelah dilakukan pembelajaran menggunakan media video dan pendekatan konstruktivisme nilai siklus I rata-rata nilai siswa 76,55. Hasil ini juga lebih baik dibandingkan rata-rata sebelumnya yaitu 65,91. Setelah siklus II hasilnya juga meningkat lagi menjadi 83,33. Kemudian hasil tersebut dibandingkan dengan indikator kinerja yang ditetapkan dalam penelitian ini sebesar 70, maka untuk siklus I hasilnya sudah tercapai, karena ketuntasan belajar siswa sudah mencapai 76,55. Apalagi setelah dilakukan pembelajaran pada siklus II target tersebut lebih meningkat lagi dari siklus 1. Gambaran tentang perkembangan hasil tes tersebut dapat dilihat pada grafik berikut ini:

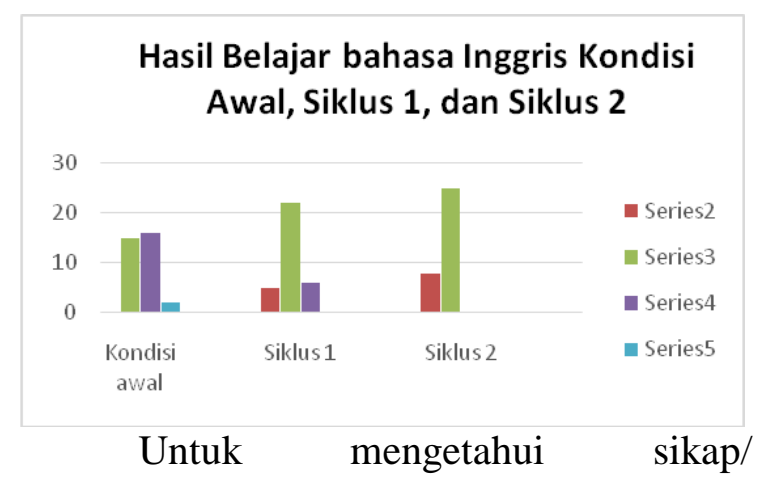

kepribadian siswa pada saat proses belajar mengajar berlangsung dengan menggunakan media video dan pendekatan konstruktivisme, Peneliti dan kolaborant mencoba mengadakan observasi dan mencatat sikap/ kepribadian siswa yang dilakukan.

Berdasarkan data observasi pada Lampiran 4b dapat diperoleh hasil prosentasi sikap/kepribadian siswa selama kegiatan belajar mengajar sebagai berikut:

\begin{tabular}{|c|c|c|c|c|}
\hline No & $\begin{array}{c}\text { Item } \\
\text { pengam } \\
\text { atan }\end{array}$ & $\begin{array}{c}\text { Pra } \\
\text { Siklus } \\
\% \\
\end{array}$ & $\begin{array}{c}\text { Siklus } \\
\text { I } \\
\% \\
\end{array}$ & $\begin{array}{c}\text { Sikl } \\
\text { us II } \\
\% \\
\end{array}$ \\
\hline 1 & Santun & 76,52 & 94,70 & $\begin{array}{c}97,7 \\
3\end{array}$ \\
\hline 2 & Disiplin & 62,88 & 84,09 & $\begin{array}{c}85,6 \\
1 \\
\end{array}$ \\
\hline 3 & $\begin{array}{l}\text { Percaya } \\
\text { Diri }\end{array}$ & 54,55 & 93,18 & $\begin{array}{c}93,1 \\
8\end{array}$ \\
\hline 4 & $\begin{array}{l}\text { Tanggun } \\
\text { g Jawab }\end{array}$ & 53,79 & 84,09 & $\begin{array}{c}86,3 \\
6\end{array}$ \\
\hline 5 & $\begin{array}{l}\text { Kerja } \\
\text { Sama }\end{array}$ & 61,36 & 75,00 & $\begin{array}{c}78,7 \\
9\end{array}$ \\
\hline & Jumlah & 309 & 431 & 442 \\
\hline & $\begin{array}{c}\text { Rata- } \\
\text { rata }\end{array}$ & 62 & 86 & 88 \\
\hline
\end{tabular}

Merujuk data diatas dapat diketahui bahwa rata-rata prosentasi sikap dan kepribadian saat proses belajar siswa pada Pra siklus adalah $62 \%$, pada siklus I adalah sebesar $86 \%$. Sedangkan siklus II 
meningkat lagi menjadi $88 \%$. Apabila dibandingkan prosentase sikap/kepribadian belajar antara siklus I dan siklus II setiap item pengamatan menunjukkan adanya kenaikan hasil. Selanjutnya apabila dibandingkan dengan indikator kinerja yang ditetapkan dalam penelitian ini adalah sebesar $70 \%$, maka rata-rata sikap/kepribadian siswa saat belajar pada siklus I sudah terpenuhi, apalagi pada siklus II hasilnya lebih terpenuhi dengan hasil 88 $\%$. Hal ini dikarenakan siswa semakin tertarik dalam menerima pelajaran dengan media video dan pendekatan konstruktivisme ini.

Untuk mengetahui pendapat siswa terhadap media video dan pendekatan pembelajaran yang digunakan, maka dilakukan wawancara. Dengan demikian dapat diketahui pendapat siswa terhadap media video dan pendekatan konstruktivisme yang digunakan dalam memparafrase teks Narrative ini, apakah sering, pernah, mengetahui, sulit, mudah, membantu dan bermanfaat.

Berdasarkan hasil wawancara, dapat diperoleh hasil prosentase pendapat siswa secara klasikal setelah menerima pelajaran sebagai berikut:

\begin{tabular}{|l|l|c|c|c|}
\hline $\begin{array}{l}\text { N } \\
\text { o }\end{array}$ & \multicolumn{1}{|c|}{$\begin{array}{c}\text { Item } \\
\text { Pertanyaan }\end{array}$} & $\begin{array}{c}\text { Pra } \\
\text { siklus } \\
\text { \% }\end{array}$ & $\begin{array}{c}\text { Siklus } \\
\text { I } \\
\text { \% }\end{array}$ & $\begin{array}{c}\text { Sikl } \\
\text { us 2 } \\
\text { \% }\end{array}$ \\
\hline 1 & $\begin{array}{l}\text { Apakah } \\
\text { anda sering } \\
\text { melihat/men } \\
\text { dengar dan } \\
\text { membaca } \\
\text { legenda } \\
\text { rakyat? }\end{array}$ & 63 & 72 & 80 \\
\hline 2 & $\begin{array}{l}\text { Apakah } \\
\text { anda pernah } \\
\text { menulis } \\
\text { legenda } \\
\text { rakyat? }\end{array}$ & 60 & 75 & 80 \\
\hline 3 & $\begin{array}{l}\text { Apakah } \\
\text { anda tahu } \\
\text { cara menulis } \\
\text { legenda }\end{array}$ & 63 & 70 & 80 \\
\hline
\end{tabular}

\begin{tabular}{|c|c|c|c|c|}
\hline & rakyat? & & & \\
\hline 4 & $\begin{array}{l}\text { Apakah sulit } \\
\text { atau mudah } \\
\text { dalam } \\
\text { memparafra } \\
\text { se legenda } \\
\text { rakyat tanpa } \\
\text { media } \\
\text { video? }\end{array}$ & & 65 & 78 \\
\hline . & $\begin{array}{l}\text { Apakah } \\
\text { media video } \\
\text { dengan } \\
\text { pendekatan } \\
\text { konstruktivi } \\
\text { sme } \\
\text { membantu } \\
\text { anda dalam } \\
\text { memparafra } \\
\text { se teks } \\
\text { Narrative? }\end{array}$ & & 70 & 83 \\
\hline 6 & $\begin{array}{l}\text { Adakah } \\
\text { manfaat } \\
\text { pembelajara } \\
\text { n } \\
\text { memparafra } \\
\text { se teks } \\
\text { Narative } \\
\text { dalam } \\
\text { kehidupan } \\
\text { sehari-hari/ } \\
\text { kedepan? }\end{array}$ & & 78 & 85 \\
\hline & Jumlah & 186 & 430 & 486 \\
\hline & Rata-rata & 62 & 72 & 81 \\
\hline
\end{tabular}

Merujuk tabel diatas dapat diketahui bahwa rata-rata hasil wawancara pendapat siswa mengenai pembelajaran memparafrase teks Narrative dengan media video dan pendekatan konstruktivisme meningkat yaitu pada siklus pra siklus adalah $62 \%$, pada siklus I adalah sebesar $72 \%$. Sedangkan pada siklus II meningkat lagi menjadi $81 \%$. Hal ini juga menunjukkan adanya sikap yang positif dari siswa sendiri terhadap media video dan pendekatan konstruktivisme dalam pembelajaran ini. Mereka merasa lebih senang dan tertarik dalam menerima pelajaran. Apabila dibandingkan dengan indikator yang ditetapkan dalam penelitian 
ini adalah sebesar $70 \%$. Seperti contohnya, siswa yang bernama Aman Afi Malik:

"Saya senang dengan gaya KBM pada pertemuan kali ini, karena saya lebih mudah memahami materi pelajaran. Adanya video tentang dongeng dan legenda membuat saya semangat belajar, karena cerita nampak lebih konkrit sehingga bisa lebih menghayati isi ceritanya disamping menghibur otak yang tegang."

Contoh selanjutnya, siswa yang bernama Debi Lestari:

"Saya gembira bisa belajar secara releks. Para pelaku dalam dongeng/legenda/ cerita dapat menghibur saya sehingga saya merasa tidak sedang belajar keras yang menguras banyak energi untuk berfikir karena tanpa disadari sebetulnya saya sedang belajar tapi terasa lagi nonton film. Padahal hasil akhirnya saya bisa memparafrase dongeng baik secara lisan maupun tertulis."

Hal ini berarti target belajar yang diharapkan dapat tercapai. Begitu juga perkembangan motivasi belajar dilihat dari aspek ini juga ada perkembangan yang positif antar hasil yang dicapai pada siklus I dan siklus II.

\subsection{Pembahasan}

Sekolah sebagai sebuah institusi pembentuk karakter dan prestasi baik akademk maupun non akademik perlu menciptakan suasana belajar yang releks tapi serius sehingga ilmu yang ditransfer oleh guru bisa ditransformasikan dalam sikap, tingkah laku dan kepribadian siswa sehari-hari disamping bisa mencerdaskan pengetahuan siswa. Ngalim Purwanto (1992:84) mengemukakan belajar adalah setiap perubahan yang relatif menetap dalam tingkah laku, yang terjadi sebagai suatu hasil dari latihan ataupun pengalaman. Maka dari itu guru perlu menerapkan media dan pendekatan pembelajaran yang bisa menarik minat siswa untuk belajar apalagi materi Bahasa Inggris yang dipandang sulit bagi siswa.
Guru sebaiknya perlu menghindari suasana belajar yang kaku, penuh dengan ketegangan, dan sarat dengan perintah dan instruksi yang membuat siswa menjadi pasif, tidak bergairah, cepat bosan, dan mengalami kelelahan. Siswa tidak tertarik terhadap pelajaran akibatnya prestasi belajar menjadi kurang baik. Sebagai guru kita harus menyadari bahwa prestasi siswa yang kurang baik itu tidak semata-mata kesalahan siswa, punya kemauan mencari solusi sekaligus mengintropeksi diri apakah selama ini sudah melaksanakan proses belajar mengajar dengan baik. Dengan mengetahui kekurangannya dapat memperbaikinya sehingga proses pembelajaran yang mendatang menjadi lebih baik.

\section{Penilaian paraphrase teks Narrative sangat penting diterapkan dalam} mengembangkan ketrampilan bahasa Inggris siswa baik secara lisan maupun tertulis karena siswa diberi kesempatan untuk mengeksplorasi dan membangun pengetahuan dan pengalamanya sendiri melalui pengamatan, pendengaran maupun diskusi dengan temanya. Apalagi pembelajaran bahasa memberikan kesempatan yang seluas-luasnya kepada siswa untuk berkomunikasi tanpa harus mengimitasi konsep/ bahasa orang lain, karena pada dasarnya manusia itu bukan robot yang hanya meniru dalam memproduksi kata per kata dan kalimat per kalimat.. Untuk mampu mengeksplorasi dan membangun pengetahuan baru maka diperlukan pengetahuan dan pengalaman yang dimiliki sebelumnya karena itu berkaitan erat dengan pengetahuan berikutnya. Guna meraih harapan seperti diatas siswa perlu:

a. Cerdas dalam berimajinasi

b. Belajar melakukan kegiatan seperti eksplorasi pengetahan dan memahami konteks tertentu.

Sedangkan kelemahannya siswa yang tidak memiliki imajinasi kuat, sedikit pengetahuan, pengalaman dan low contect biasanya sering gagal dalam mengeksplorasi dan membangun 
pengetahuan baru sehingga hasil kerjanya sangat terbatas, untuk penilaian memerlukan banyak waktu, bagi guru untuk melakukan penskoran apalagi kelasnya besar dan sangat tergantung pada kemampuan siswa dan guru. Untuk melakukan penilaian seperti diatas perlu strategi pembelajaran yang mampu menarik siswa sekaligus menggerakkan siswa agar aktif kreatif, disamping itu guru sudah saatnya harus memiliki tanggungjawab secara professional.

Mulai sekarang sudah sewajarnya kita mulai memberdayakan siswa dalam kegiatan PBM. Strategi pembelajaran bahasa Inggris yang melibatkan peran serta aktif siswa yang hendaknya kita pilih dan kita kembangkan. Seorang guru dituntut untuk selalu melibatkan siswa dalam kegiatan PBM. Dengan demikian siswa termotivasi dalam PBM. Dengan adanya motivasi yang baik tentunya membawa dampak yang baik pula terhadap prestasi belajar siswa. Untuk itu hendaknya seorang guru jangan cepat merasa puas dengan prestasi yang telah dicapai. Namun guru harus memperbaiki kekurangankekurangannya dan terus menciptakan inovasi-inovasi terbaru demi kemajuan pendidikan.

\section{Penutup}

Dari hasil kompetensi Narrative Texs, kemampuan pembelajaran siswa meningkat dengan menggunakan media video dan pendekatan konstruktivisme . Hal tersebut dibuktikan dengan nilai sebelumnya dengan nilai rata-rata hanya 65,91 . Setelah diadakan KBM pada Siklus I, nilai rata-rata siswa 76,55 . Selanjutnya, pada KBM Siklus II menggunakan media video dan pendekatan konstruktivisme, nilai rata-rata siswa meningkat menjadi 83,33.Hal tersebut menunjukkan kemampuan siswa dalam memparafrase teks Narrative kelas X MIPA 4 SMA Negeri 1 Paguyangan semakin baik. Sehingga, belajar dengan media video dan pendekatan konstruktivisme, dapat menjadi alternatif metode pembelajaran yang cukup baik, karena masing-masing siswa tertarik dalam mendongeng dengan bahasa sendiri tanpa merubah makna dari isi dongeng yang dipelajari.

Belajar dengan media video dan pendekatan konstruktivisme dapat diterapkan pada aspek writing pada kelas yang berbeda dan dapat pula dikembangkan pada kelas XI ataupun kelas XII.Untuk mendapatkan temuan yang lebih signifikan maka penelitian ini perlu dilanjutkan dengan siklus berikutnya.

\section{DAFTAR PUSTAKA}

Arsyad, Azhar. 2014. Media Pembelajaran. Jakarta: Rajawali Press

.Arikunto, Suharsimi. 2010. Penelitian Tindakan Kelas. Jakarta: Bumi Aksara.

Admojo, dkk, 2005. Kamus Lengkap Inggris-Indonesia,Indonesiainggris). Semarang: CV. Widya Karya.

Arief S Sadiman. Et al 2003. Media Pendidikan,Pengertian,

Pengembangan dan Pemanfaatannya. Jakarta: PT Raja Grafindo Persada.

Canning -Wilson,.(2000). Practical aspects of using video in the Foreign Language Classroom. The Internet TESL journal 6 (11) Available at. http://iteslj.org

Daryanto. 2012. Media Pembelajaran. Bandung: Satu Nusa.

Habib. 2011. Optimalisasi writing skill pada Narrative Texts melalui Penggunaan Youtube Video. Semarang: lembaga Penjaminan Mutu Pendidikan (LPMP) Jawa Tengah

https://myfortuner.wordpress.com/2010/08/

04/teori-teori-belajar-dan-

pembelajaran-menurut-ahli// Selasa, 11 Sept 2018. 21.09

Hamalik, O. 2008. Proses Belajar Mengajar. Jakarta: PT. Bumi Aksara.

Hamalik, O. 2008. Kurikulum dan Pembelajaran. Jakarta: PT. Bumi Aksara.

Harimurti Kridalaksana (2008) Kamus Linguistik (edisi ke-4). Jakarta: 
Gramedia Pustaka Utama. ISBN 978979-22-3570-8

http://www.slideshare.net/abeyow/pembelaj aran-kontekstualcontextual-

teaching-learning-ctl. 11:26 , sabtu, 19 March 2016

Mursid, S. 2008. Penelitian Pendidikan Bahasa. Semarang: Unness Press.

Rukmini, D, 2010. Evaluating A Text for A Model. Semarang: Unnes Press

http://simpuh.kemenag.go.id/regulasi/perme ndiknas_24 06.pdf, Senin, 17 September 2018. 10:31.

Sanaky, Hujair AH. 2013. Media Pembelajaran Interaktif-Inovatif. Yogyakarta: Kaukaba Dipantara.

Sanjaya, Wina. 2010. Perencanaan dan Desain Sistem Pembelajaran. Jakarta: Prenada Media Group.

Subyantoro. 2009. Penelitian Tindakan Kelas. Semarang: Rumah Indonesia.

Tarigan, Henry Guntur. 2008. Menulis sebagai Suatu Ketrampilan Berbahasa. Bandung: Angkasa.

Trianto, 2007. Model Pembelajaran Terpadu dalam Teori dan Praktek. Jakarta: Prestasi Pustaka

Widyatiningtyas, R. 2010. Peranan Guru dalam Melakukan Penilaian Keterampilan Proses EDUCARE: Jurnal Pendidikan dan Budaya 
